\title{
Microwave Absorbing Properties of MnAl Alloy Powder
}

\author{
Pan Shunkang \\ Liu Ye, \\ Lin Peihao, \\ Rao Guanghui, \\ Zhou Huaiying, \\ Cheng
}

Lichun

Guilin University of Electronic Technology, Guilin 541004, China

\begin{abstract}
Mn}_{55} \mathrm{Al}_{45}$ alloy powder was prepared by the combined use of arc melting, high energy ball milling and tempering heat treatment process. The phase structure and the microstructure of the alloy powder were analyzed by X-ray diffraction (XRD) and scanning electron microscopy (SEM), and then their microwave absorbing properties were tested by a vector network analyzer. The results show that an increase of phases for $\mathrm{Al}_{2} \mathrm{Mn}_{3}$ and $\mathrm{Al}_{11} \mathrm{Mn}_{14}$ are accompanied by the increased milling time; the resonant frequency and the absorption peaks of $\varepsilon^{\prime \prime}$ and $\mu^{\prime \prime}$ shift towards lower frequency region simultaneously. A better result of electromagnetic properties is brought to the alloy powder when the ball milling time is set to $18 \mathrm{~h}$ in first attempt. While the ball milling time is increased to $24 \mathrm{~h}$ during later experiment, the minimum reflectivity value reaches to $-28 \mathrm{~dB}$ at a frequency of $16 \mathrm{GHz}$. $\mathrm{The} \mathrm{Al}_{2} \mathrm{Mn}_{3}$ phase increases with an artificial increase of tempering temperature. The $\mathrm{Mn}_{55} \mathrm{Al}_{45}$ alloy powder ball milled for $18 \mathrm{~h}$ and tempered at $400{ }^{\circ} \mathrm{C}$ exhibits preferably comprehensive microwave absorbing properties in the range of $6 \sim 8 \mathrm{GHz}$. The minimum reflectivity value and absorption peak frequency at the coating thickness of $2.0 \mathrm{~mm}$ are $-26.4 \mathrm{~dB}, 17 \mathrm{GHz}$, respectively.
\end{abstract}

Key words: MnAl alloy; absorbing material; high energy ball milling; tempering heat treatment

With the rapid development of science and technology, the application of electromagnetic technology has brought material civilization to the communities. However, the serious problems of the electromagnetic interference and electromagnetic compatibility have become increasingly prominent in recent years. $\mathrm{R}$ and $\mathrm{D}$ of microwave absorbing materials for controlling the radioactive electromagnetic pollution is a pressing matter at the moment. In the civil field, absorbing materials, have been widely used in the fields of radio, television, radar, microwave anechoic chamber and electronic devices. In military field, stealth weapon plays an important strategic role in wars in future. Microwave absorbing materials are the key materials for stealth weapon; the functionality is to reduce or eliminate the target detection performance ${ }^{[1-6]}$. For this reason, the microwave absorbing materials are vitally important for both civil and military field ${ }^{[7-12]}$. Microwave absorbing materials stand at an important position in stealth technology owing to their easy preparation, the properties of outstanding absorbing performance ${ }^{[13]}$. The intention of making them thin, good thermal stability, light in weight, as well as corrosion resistance is of great significance to the application of magnetic microwave absorbing materials.

$\mathrm{MnAl}$ alloys are guite useful as microwave absorbers due to their advantages with respect to good thermal stability, corrosion resistance and light in weight ${ }^{[14]}$. But as permanent magnets, MnAl alloys have shortcomings such as their difficulty of fabrication and high costs that prevent them from being used as permanent magnets. A great value would be brought to either theory or practice through proper treatments to further improve properties. The purpose of this paper is to investigate the effects of different high-energy ball milling time and different tempering temperatures on absorption properties of $\mathrm{Mn}_{55} \mathrm{Al}_{45}$ alloy.

\section{Experiment}

Received date: February 25, 2015

Foundation item: National Natural Science Foundation of China (50961005, 51361007); the Natural Science Foundation of Guangxi (2012GXNSFGA06002, 2013GXNSFAA019295)

Corresponding author: Pan Shunkang, Ph. D., Professor, School of Materials Science and Engineering, Guilin University of Electronic Technology, Guilin 541004, P. R. China, Tel: 0086-773-2291434, E-mail: skpan88@163.com

Copyright (C 2016, Northwest Institute for Nonferrous Metal Research. Published by Elsevier BV. All rights reserved. 
The selected starting materials $\mathrm{Al}$ and $\mathrm{Mn}$ had purities no less than $99.5 \%$. The experimental powder was prepared based on the chemical composition of $\mathrm{Mn}_{55} \mathrm{Al}_{45}$. The sample was smelted in an electric arc furnace with a three-time-rollover under the protection of high purity argon. The $\mathrm{MnAl}$ ingot was homogenized for $24 \mathrm{~h}$ at $1050{ }^{\circ} \mathrm{C}$ in vacuum, then quenched in ice water after the homogenization heat treatment, and crushed into coarse powder with particle size smaller than $0.5 \mathrm{~mm}$. The coarse powder was ground under the protection of ethanol for 12 , 18 and $24 \mathrm{~h}$, by QM-1SP planet ball milling machine at the speed of $300 \mathrm{r} / \mathrm{min}$. The mass ratio of the balls to the powder was 20:1. Hereafter, the powder milled for $18 \mathrm{~h}$ was tempered at 200, 400 and $600{ }^{\circ} \mathrm{C}$. The prepared $\mathrm{MnAl}$ powder was mixed with paraffin in ratio of 30:70 (by volume). The mixture was made into a coaxial ring with a thickness of $3.5 \mathrm{~mm}$, outer diameter of $7 \mathrm{~mm}$, and inner diameter of $3 \mathrm{~mm}$. The complex permeability and the complex permittivity of the samples were measured with vector network analyzer (HP8722ES) in the frequency range of $2 \sim 18 \mathrm{GHz}$, and the measurement data were taken in each $0.08 \mathrm{GHz}$. According to the theory of equivalent transmission lines, calculation formula of the single absorbing material reflectivity $R$ could be deduced as following ${ }^{[15]}$ :

$$
R=20 \lg \left|\frac{\sqrt{\frac{\mu_{\mathrm{r}}}{\varepsilon_{\mathrm{r}}}} \cdot \tanh \left(\mathrm{j} \frac{2 \pi f d}{c} \sqrt{\mu_{\mathrm{r}} \varepsilon_{\mathrm{r}}}\right)-1}{\sqrt{\frac{\mu_{\mathrm{r}}}{\varepsilon_{\mathrm{r}}}} \cdot \tanh \left(\mathrm{j} \frac{2 \pi f d}{c} \sqrt{\mu_{\mathrm{r}} \varepsilon_{\mathrm{r}}}\right)+1}\right|
$$

where, $\varepsilon_{\mathrm{r}}, \mu_{\mathrm{r}}$ and $d$ denote the relative permittivity, relative permeability, and thickness of absorbing material, respectively, $f$ is the frequency of electromagnetic wave, $c$ is the velocity of electromagnetic wave in free space (the speed of light), and $\mathrm{j}$ is the imaginary unit.

\section{Results and Discussion}

\subsection{Morphology and Structure of the MnAl powder}

The SEM images of the as-milled $\mathrm{Mn}_{55} \mathrm{Al}_{45}$ powders are shown in Fig.1. As it can be seen from the image, the particle size without ball milling is less than $0.35 \mathrm{~mm}$. The particle size is less than $5 \mu \mathrm{m}$ for the powder milled for 12 $\mathrm{h}$. With the increase of the milling time, more irregular powder was milled into flaky particles. When the ball milling time is 18 and $24 \mathrm{~h}$, the powder particle sizes become less than $5 \mu \mathrm{m}$.

The XRD patterns of the $\mathrm{Mn}_{55} \mathrm{Al}_{45}$ powders milled for different milling time ranging from $0 \mathrm{~h}$ to $24 \mathrm{~h}$ are demonstrated in Fig.2. The as-milled powder mainly consists of $\mathrm{Al}_{8} \mathrm{Mn}_{5}, \mathrm{Al}_{2} \mathrm{Mn}_{3}$ and $\mathrm{Al}_{11} \mathrm{Mn}_{14}$ phases. The number of new phase such as $\mathrm{Al}_{2} \mathrm{Mn}_{3}$ and $\mathrm{Al}_{11} \mathrm{Mn}_{14}$ increases with the increase of milling time. But at different milling time, the diffraction peaks are unobviously broadened.

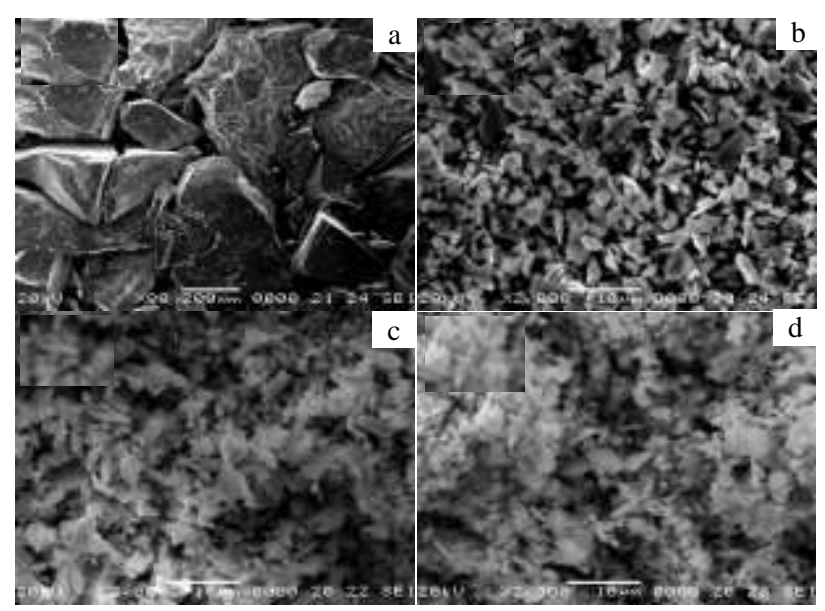

Fig.1 SEM morphologies of $\mathrm{Mn}_{55} \mathrm{Al}_{45}$ alloy powders milled for different time: (a) $0 \mathrm{~h}$, (b) $12 \mathrm{~h}$, (c) $18 \mathrm{~h}$, and (d) $24 \mathrm{~h}$

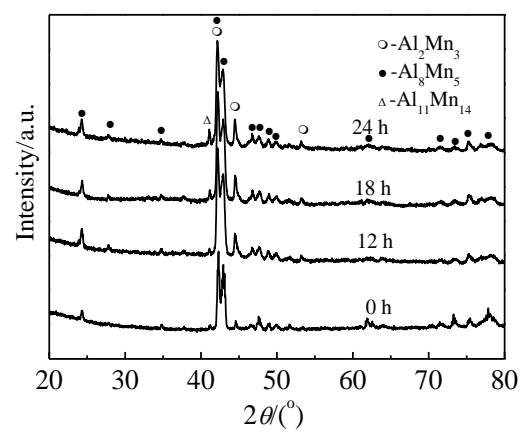

Fig.2 XRD patterns of MnAl powders milled for different milling time

The relationships between the frequency and imaginary parts of complex permeability $\left(\mu^{\prime \prime}\right)$ and complex permittivity $\left(\varepsilon^{\prime \prime}\right)$ at different milling time in the frequency range of $2 \sim 18$ $\mathrm{GHz}$ are demonstrated in Fig.3. It shows that the resonant frequency moves towards lower frequency region as the milling time increases. This is mainly because the particle size becomes fine, and the relative contents of $\mathrm{Al}_{2} \mathrm{Mn}_{3}$, $\mathrm{Al}_{11} \mathrm{Mn}_{14}$ increase, which makes the crystal defects increasing and conductivity decreasing, and finally causes the resonant frequency of $\varepsilon^{\prime \prime}$ to move to lower frequency. As the particle size becomes fine, the crystal integrity is damaged more seriously and the anisotropy field $(\mathrm{Ha})$ decreases correspondingly. According to the relationship between the resonant frequency of $\mu^{\prime \prime}\left(f_{\mathrm{r}}\right)$ and $\mathrm{Ha}$, the resonant frequency of $\mu^{\prime \prime}$ moves towards lower frequency as the milling time increases.

The reflectivities of the powders at different milling time were computed from Formula (1) when the coating thickness $d=2.0 \mathrm{~mm}$, in the range of frequency between $2 \mathrm{GHz}$ to 18 GHz, as shown in Fig. 4 and Table 1. The as-milled powder have several absorption peaks in the frequency range of $2 \sim 18$ 

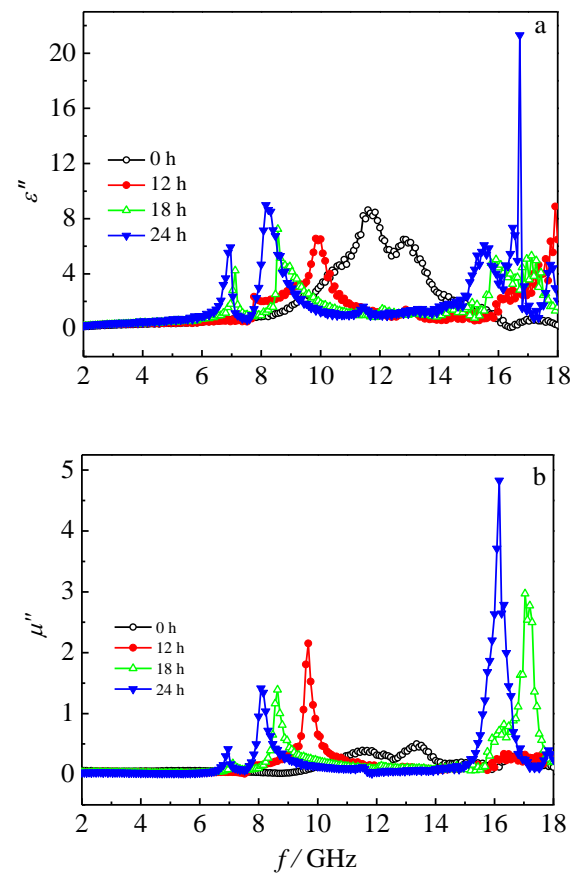

Fig.3 Electromagnetic parameters of $\mathrm{Mn}_{55} \mathrm{Al}_{45}$ powder at different milling time: (a) curves of $\varepsilon^{\prime \prime}$ vs $f$ and (b) curves of $\mu^{\prime \prime}$ vs $f$

$\mathrm{GHz}$, and absorption peak frequency moves to lower frequency as the milling time increase. These characteristics are the same with the fact that the resonant frequencies of $\varepsilon^{\prime \prime}$ and $\mu^{\prime \prime}$ increase with increase of the milling time. As we know, the magnetic behavior may be modulated by the dielectric behavior, which may lead to the coupling between these two parameters. The imaginary parts $\left(\varepsilon^{\prime \prime}\right.$ and $\left.\mu^{\prime \prime}\right)$ represent the losses of electric and magnetic energies. It means that the dielectric loss and magnetic loss will affect the reflectivity value of the powder. After $18 \mathrm{~h}$ ball-milling, the powder has 3 absorption peaks in the frequency range of $8 \sim 18 \mathrm{GHz}$, the reflectivity value is less than $-10 \mathrm{~dB}$, and has an excellent bandwidth effect. After $24 \mathrm{~h}$ ball-milling, the minimum reflectivity value decreases to $-28 \mathrm{~dB}$ at $16 \mathrm{GHz}$.

\subsection{Effect of tempering temperature on the microstructure and magnetic properties of $\mathrm{Mn}_{55} \mathbf{A l}_{45}$ powder}

Fig. 5 shows the XRD patterns of $\mathrm{Mn}_{55} \mathrm{Al}_{45}$ powders before and after tempering heat treatment. The powders before and after tempering at $200{ }^{\circ} \mathrm{C}$ mainly consist of $\mathrm{Al}_{2} \mathrm{Mn}_{3}$ and $\mathrm{Al}_{8} \mathrm{Mn}_{5}$ phases. While the powder after tempering at $400^{\circ} \mathrm{C}$, the phase composition of $\mathrm{Mn}_{55} \mathrm{Al}_{45}$ powder includes $\mathrm{Al}_{11} \mathrm{Mn}_{14}$, $\mathrm{Mn}_{2} \mathrm{O}_{3}, \mathrm{Al}_{2} \mathrm{Mn}_{3}$ and $\mathrm{Al}_{8} \mathrm{Mn}_{5}$ phases. For the powder tempered at $600{ }^{\circ} \mathrm{C}$, its phase composition includes $\mathrm{Al}_{2} \mathrm{Mn}_{3}, \mathrm{Al}_{8} \mathrm{Mn}_{5}$, $\mathrm{Mn}_{2} \mathrm{O}_{3}$ and $\mathrm{Mn}_{3} \mathrm{O}_{4}$. The relative amount of $\mathrm{Al}_{2} \mathrm{Mn}_{3}$ phase increases with the increase of tempering temperature, and for the powder tempered at $600^{\circ} \mathrm{C}$, it is obviously oxidized.
Table 1 Minimum reflectivity value vs milling time

\begin{tabular}{ccccc}
\hline Milling time/h & 0 & 12 & 18 & 24 \\
\hline Reflectivity, $R / \mathrm{dB}$ & -25.8 & -17 & -26.4 & -28 \\
\hline
\end{tabular}

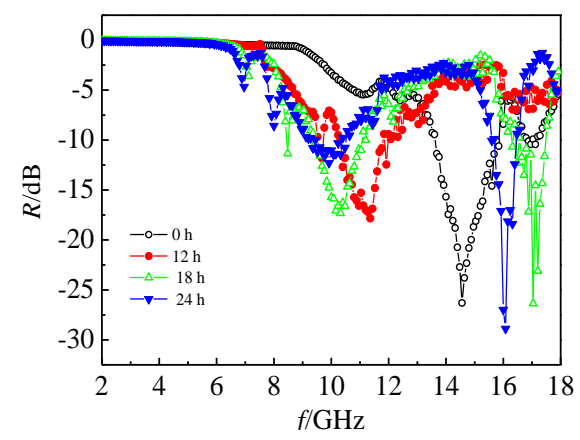

Fig.4 Reflectivity values of $\mathrm{Mn}_{55} \mathrm{Al}_{45}$ powder at different milling time

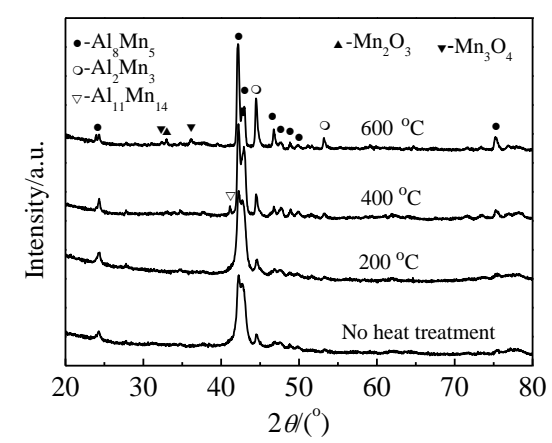

Fig.5 XRD patterns of MnAl powders at different tempering temperatures

The relationship between the frequency and the complex permeability and permittivity at different tempering temperatures in the frequency range of $2 \sim 18$ $\mathrm{GHz}$ are demonstrated in Fig.6. The resonant frequency of $\varepsilon^{\prime \prime}$ declines at the beginning and then rises with the increase of temperature. The resonant frequency of $\varepsilon^{\prime \prime}$ declines when the temperature is $200{ }^{\circ} \mathrm{C}$, and that is related to the reduced internal energy and increased activation energy, which leads the peak frequency of $\varepsilon^{\prime \prime}$ to move to lower frequency. When the tempering temperature is $400{ }^{\circ} \mathrm{C}$, the content of $\mathrm{Al}_{2} \mathrm{Mn}_{3}$ increases and $\mathrm{Mn}_{2} \mathrm{O}_{3}$ is generated, which makes the activation energy decrease, and then causes the resonant frequency of $\varepsilon^{\prime \prime}$ to move to higher frequency. While the tempering temperature is $600^{\circ} \mathrm{C}$, more $\mathrm{Mn}_{2} \mathrm{O}_{3}$ and $\mathrm{Mn}_{3} \mathrm{O}_{4}$ are generated as well as more $\mathrm{Al}_{2} \mathrm{Mn}_{3}$ are precipitated, which further reduce the saturation magnetization, and the resonant frequency of $\varepsilon$ " moves further to higher frequency. In this view, the resonant frequency can be affected by the tempering temperature. According to the 

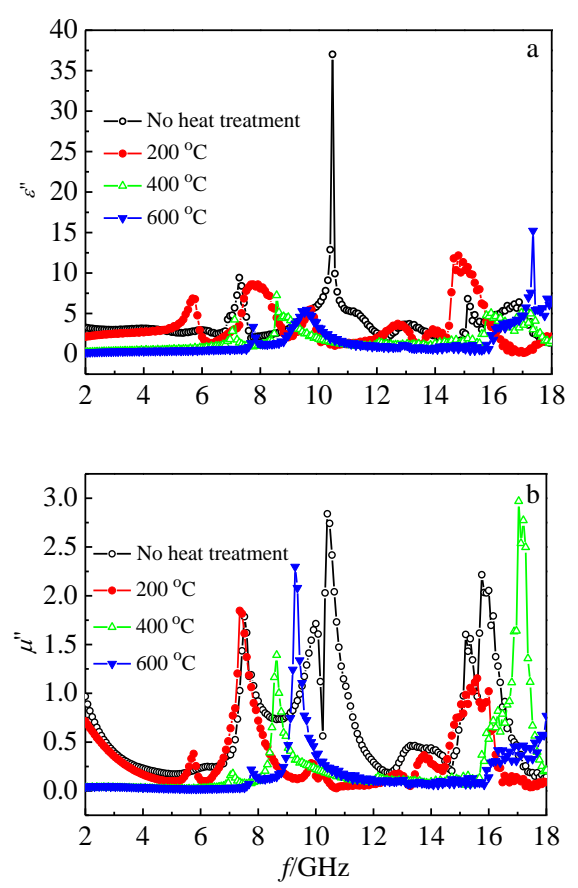

Fig.6 Electromagnetic parameters of $\mathrm{Mn}_{55} \mathrm{Al}_{45}$ powder at different tempering temperatures: (a) curves of $\varepsilon^{\prime \prime}$ vs $f$ and (b) curves of $\mu^{\prime \prime}$ vs $f$

relationship between internal energy and $\mathrm{Al}_{2} \mathrm{Mn}_{3}, \mathrm{Mn}_{2} \mathrm{O}_{3}$ phase, the saturation magnetization $(M \mathrm{~s})$ increases at the beginning and then declines with the increase of tempering temperature. The resonant frequency of $\mu$ " moves towards a lower frequency region, which results from the enhancement of $M \mathrm{~s}$. While the tempering temperature increases to $400{ }^{\circ} \mathrm{C}$, with the weakening of $M \mathrm{~s}$, the resonant frequency moves towards a high frequency region. When the tempering temperature is $600{ }^{\circ} \mathrm{C}$, the contents of $\mathrm{Mn}_{2} \mathrm{O}_{3}$ and $\mathrm{Al}_{2} \mathrm{Mn}_{3}$ phases increase and the formation of $\mathrm{Mn}_{3} \mathrm{O}_{4}$ phase, which makes the saturation magnetization decreasing more, leads the resonant frequency of $\mu^{\prime \prime}$ to move to higher frequency.

The reflectivities of the powders were computed from Formula (1) at different tempering temperatures when coating thickness $d=2.0 \mathrm{~mm}$, in the frequency range from 2 $\mathrm{GHz}$ to $18 \mathrm{GHz}$, as shown in Fig.7 and Table 2. The reason that the absorption peak frequency moves towards a lower frequency region results from the enhancement of dielectric loss and magnetic loss. Generally, microwave absorption properties of materials are determined by the dielectric and magnetic losses. It is concluded that the dielectric and magnetic losses are enhanced, which may result in an improvement of the microwave absorption properties ${ }^{[16]}$. While the temperature increases to $400{ }^{\circ} \mathrm{C}$, the absorption peak frequency moves towards a higher frequency region. When the temperature is $600{ }^{\circ} \mathrm{C}$, the absorption peak
Table 2 Minimum reflectivity value of $\mathrm{Mn}_{55} \mathrm{Al}_{45}$ powder at different tempering temperatures

\begin{tabular}{ccccc}
\hline$T_{\text {tempering }} /{ }^{\circ} \mathrm{C}$ & No heat treatment & 200 & 400 & 600 \\
\hline Reflectivity, $R / \mathrm{dB}$ & -17.2 & -24.8 & -26.4 & -13.2 \\
\hline
\end{tabular}

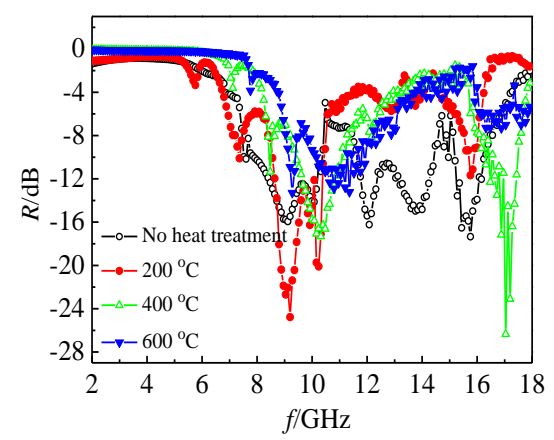

Fig.7 Reflectivity value of $\mathrm{Mn}_{55} \mathrm{Al}_{45}$ powder at different tempering temperatures

frequency moves further towards a higher frequency region. These characteristics are the same with that resonant frequency increase with the increase of tempering temperature. The minimum reflectivity values of no heat treatment, at 200 and $400{ }^{\circ} \mathrm{C}$ tempering temperatures are $-17.2,-24.8$, and $-26.4 \mathrm{~dB}$, respectively. In view of this, the minimum reflectivity value can be reduced through the tempering temperature. For powder dealt with $18 \mathrm{~h}$ ball-milling and with no heat treatment, 200 and $400{ }^{\circ} \mathrm{C}$ heat treatment, they all have 3 or 4 absorption peaks in the range of $6 \mathrm{GHz}$ to $18 \mathrm{GHz}$, which shows that $\mathrm{Mn}_{55} \mathrm{Al}_{45}$ has an excellent broadband absorption effect. But after $600{ }^{\circ} \mathrm{C}$ tempering, the powder has only 2 absorption peaks in the frequency region of $9 \mathrm{GHz}$ to $12 \mathrm{GHz}$, and the broadband absorption effect is enhanced, and the minimum reflectivity value is $-13.2 \mathrm{~dB}^{[17-20]}$.

\section{Conclusions}

1) $\mathrm{Mn}_{55} \mathrm{Al}_{45}$ powder mainly consists of $\mathrm{Al}_{8} \mathrm{Mn}_{5}, \mathrm{Al}_{2} \mathrm{Mn}_{3}$ and $\mathrm{Al}_{11} \mathrm{Mn}_{14}$ phase. The relative amounts of $\mathrm{Al}_{2} \mathrm{Mn}_{3}$, $\mathrm{Al}_{11} \mathrm{Mn}_{14}$ phases increase with the increase of milling time.

2) The as-milled powder has several absorption peaks in the frequency range of $2 \sim 18 \mathrm{GHz}$, and the absorption peak frequency moves to lower frequency as the milling time increases. After $24 \mathrm{~h}$ milling, the minimum reflectivity value reaches about $-28 \mathrm{~dB}$ at $16 \mathrm{GHz}$ frequency.

3) The powders before and after tempering at $200{ }^{\circ} \mathrm{C}$ mainly consist of $\mathrm{Al}_{2} \mathrm{Mn}_{3}$ and $\mathrm{Al}_{8} \mathrm{Mn}_{5}$ phase. While the phase composition of $\mathrm{Mn}_{55} \mathrm{Al}_{45}$ powder includes $\mathrm{Al}_{11} \mathrm{Mn}_{14}$, $\mathrm{Mn}_{2} \mathrm{O}_{3}, \mathrm{Al}_{2} \mathrm{Mn}_{3}$ and $\mathrm{Al}_{8} \mathrm{Mn}_{5}$ phase after $400^{\circ} \mathrm{C}$ tempering. For the powder after $600{ }^{\circ} \mathrm{C}$ tempering, its phase composition includes $\mathrm{Al}_{2} \mathrm{Mn}_{3}, \mathrm{Al}_{8} \mathrm{Mn}_{5}, \mathrm{Mn}_{2} \mathrm{O}_{3}$ and $\mathrm{Mn}_{3} \mathrm{O}_{4}$ phase. The relative amount of $\mathrm{Al}_{2} \mathrm{Mn}_{3}$ phase increases with the increase of tempering temperature. 
4) The absorption peak frequency moves towards a lower frequency region at the beginning. While the temperature increases to $400{ }^{\circ} \mathrm{C}$, the absorption peak frequency moves towards a high frequency region. Absorption peak frequency moves further towards a higher frequency region when the temperature is $600^{\circ} \mathrm{C}$. The minimum reflectivity values of no heat treatment at 200,400 , and $600{ }^{\circ} \mathrm{C}$ tempering temperatures are $-17.2,-24.8,-26.4 \mathrm{~dB}$, respectively.

\section{References}

1 Matsumoto M, Miyata Y. IEEE Transactions on Magnetics[J], 1997, 33(6): 4459

2 Maddocks A J. Measurement Science and Technology[J], 2006, 153(6): 293

3 Zhang Jian, Zhang Wenyan, Xi Zhengping. Rare Metal Materials and Engineering [J], 2008, 37(4): 504 (in Chinese)

4 Yang Huijing, Cao Maosheng, Li Yong et al. Advanced Optical Materials[J], 2014, 2(3): 214

5 Li Huafang. Safety[J], 2013, 4: 27

6 Xu Xuechun. Aerodynamic Missile Journal[J], 2013, 5: 87

7 Qiu Qin, Zhang Yanqing, Zhang Xiong. Electronic Components and Materials[J], 2009, 28(8): 78

8 Wang Shenghao, Wen Feng, Hao Wanjun et al. Environmental Science and Technology[J], 2006, 29(12): 96

9 Sharma R, Agarwala R C, Agarwala V. Materials Letters[J],
2008, 62: 2233

10 Wen Bo, Cao Maosheng, Lu Mingming et al. Advanced Materials[J], 2014, 26(21): 3484

11 Cao Maosheng, Yang Jian, Song Weili et al. ACS Applied Materials Interfaces[J], 2012, 4(12): 6948

12 Meena R S, Bhattachrya S, Chatterjee R. Materials Science and Engineering [J], 2010, 171: 133

13 Liu Xiangxuan, Chen Xin, Wang Xuanjun et al. Surface Technology[J], 2013(4): 105

14 Deng Longjiang, Zhou Peiheng, Weng Xiaolong. Functional Materials[J], 2005, 2(4): 8

15 Yang Yingshan, Han Junde. The Magnetic Body Manual (Middle Volume)[M]. Beijing: Metallurgical Industry Press 1984: 162 (in Chinese)

16 Shi Xiaoling, Cao Maosheng, Yuan Jie et al. Applied Physics Letters[J], 2009, 95(16): 163108

17 Lv Ruitao, Kang Feiyu, Wei Jinquan et al. Journal of Inorganic Materials[J], 2008, 23(1): 23

18 Liao Shaobin. Ferromagnetics[M]. Beijing: Science Press, 1988: 41 (in Chinese)

19 Meng Xiangdong, Liu Yu, Li Haibo. Journal of Jilin Normal University, Natural Science Edition[J], 2009, 4: 34 (in Chinese)

20 Zeng Q, Baker I, Cui J B et al. Journal of Magnetism and Magnetic Materials[J], 2007, 308(2): 214

\title{
$\mathrm{MnAl}$ 粉体微波吸收特性的研究
}

\author{
潘顺康, 刘 烨, 林培豪, 饶光辉, 周怀营, 成丽春
}

(桂林电子科技大学, 广西 桂林 541004)

\begin{abstract}
摘 要: 采用电弧熔炼和高能球磨以及回火热处理工艺制备了 $\mathrm{Mn}_{55} \mathrm{Al}_{45}$ 合金粉体, 使用 $\mathrm{SEM} 、 \mathrm{XRD}$ 和网络矢量分析仪分析了球磨时间和 回火温度对 $\mathrm{Mn}_{55} \mathrm{Al}_{45}$ 合金微粉的形貌、相结构及吸波性能的影响。结果表明：随球磨时间增加，粉体中 $\mathrm{Al}_{2} \mathrm{Mn}_{3}$ 和 $\mathrm{Al}_{11} \mathrm{Mn}_{14}$ 的相对含量会 随之而增加; 粉体的复介电常数虚部、复磁导率虚部的共振峰频率和吸收峰频率都随球磨时间的增加而逐渐向低频移动, 球磨 $18 \mathrm{~h}$ 的粉 体有很好的频宽效果; 球磨 $24 \mathrm{~h}$ 时, 反射率峰值在 $16 \mathrm{GHz}$ 处达到 $-28 \mathrm{~dB}$ 。随回火温度的增加, 粉体中的 $\mathrm{Al}_{2} \mathrm{Mn}_{3}$ 增多, 球磨 $18 \mathrm{~h}$ 后和经 $400{ }^{\circ} \mathrm{C}$ 回火处理的粉体, 在 $6 \sim 18 \mathrm{GHz}$ 频段内有较好的综合吸波性能。在吸波涂层厚度 $d=2.0 \mathrm{~mm}$ 下, $400{ }^{\circ} \mathrm{C}$ 回火处理的粉体在 $17 \mathrm{GHz}$ 频率处具有最小反射率值为 $-26.4 \mathrm{~dB}$ 。
\end{abstract}

关键词: $\mathrm{MnAl}$ 合金; 吸波材料; 高能球磨; 回火热处理

作者简介: 潘顺康, 男, 1973 年生, 博士, 教授, 桂林电子科技大学材料科学与工程学院, 广西 桂林 541004, 电话: 0773-2291434, E-mail: skpan88@163.com 